ZDZISŁAW ŻYGULSKI, JR.

\title{
Further Battles for the Lisowczyk (Polish Rider) by Rembrandt
}

Few paintings included among outstanding creations of modern painting provoke as many disputes, polemics and passionate discussions as Rembrandt's famous Lisowczyk, which is known abroad as the Polish Rider ${ }^{1}$. The painting was purchased by Michał Kazimierz Ogiński, the grand hetman of Lithuania in the Netherlands in 1791 and given to King Stanislaus Augustus in exchange for a collection of 420 guldens' worth of orange trees ${ }^{2}$. It was added to the royal collection in the Łazienki Palace and listed in the inventory in 1793 as a "Cosaque à cheval" with the dimensions $44 \times 54$ inch i.e. $109,1 \times 133,9 \mathrm{~cm}$ and price 180 ducats.

The subsequent history of the painting is well known. In 1798, after the King's death, the Lisowczyk went by descent to Prince Józef Poniatowski, and in 1813 by descent to his sister Therese Tyszkiewicz. In 1814 it was purchased by Franciszek Ksawery Drucki-Lubecki and soon afterwards sold for 500 ducats to the bishop of Vilnius, Hieronim Stroynowski, from whom it was inherited by Walerian Stroynowski residing at the palace in Horochów in Volhynia. Again by descent, the painting went to Valerie Stroynowska-Tarnowska who included it in her dowry when marrying Jan Feliks Tarnowski of the Castle of Dzików. The Lisowczyk remained there until 1910 when Count Zdzisław Tarnowski decided to sell it through the Carfax Gallery in London and Knoedler and Co. in New York. The pur- chaser was an outstanding American collector, Henry Clay Frick, king of coke and steel who resided in Pittsburgh and since 1920 in New York where, in a specially designed building, he opened an amazingly beautiful gallery ${ }^{3}$. The transaction, which arouse public indignation in Poland, was carried out through Roger Fry, a writer, painter and art critic who occasionally acted as a buyer of pictures. The price including his commission amounted to 60,000 English pounds, that was a little above 300,000 dollars, but not half a million as was rumoured in Poland later.

In his letter to the King, Hetman Ogiński called the rider, presented in the painting "a Cossack on horseback". However, already in 1797 the King himself recognized the rider as a soldier of the Lisowski corps. The name "Lisowczyk" was generally accepted by the Polish circle, especially so that after the death of Alexander Lisowski, the commander of the famous light cavalry, his place was taken by Stanislaus Stroynowski, a nobleman from the Kraków voivodeship and member of the family from which the later owners of the painting descended ${ }^{4}$. The Lisowczyk in the gallery of the Dzików Castle attracted much attention and was recorded in numerous etchings and copied by painters, also by Juliusz Kossak. It was also known abroad. Wilhelm Bode, a famous expert in Dutch painting, in his book published in 


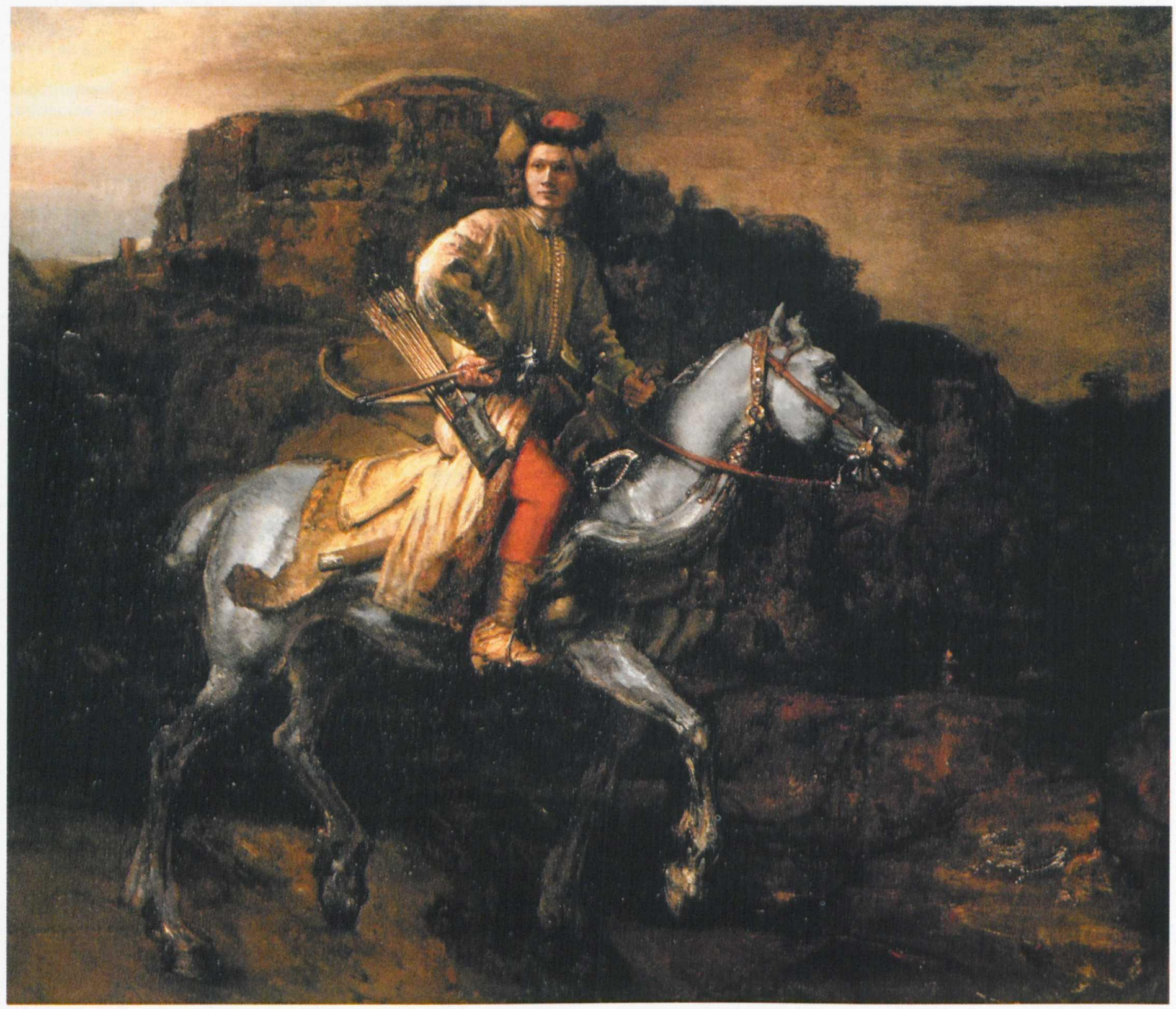

1) Rembrandt's «Lisowczyk» (Polish Rider). Frick Collection, New York.

1883 recognized it as a representation of a Polish magnate in the national costume ${ }^{5}$. However, even before the picture left Poland, two Polish experts in European painting, Jan Boloz-
Antoniewicz and Jerzy Mycielski suggested that in spite of the Polish garment the model for the rider was the artist's son Titus. ${ }^{6}$ 


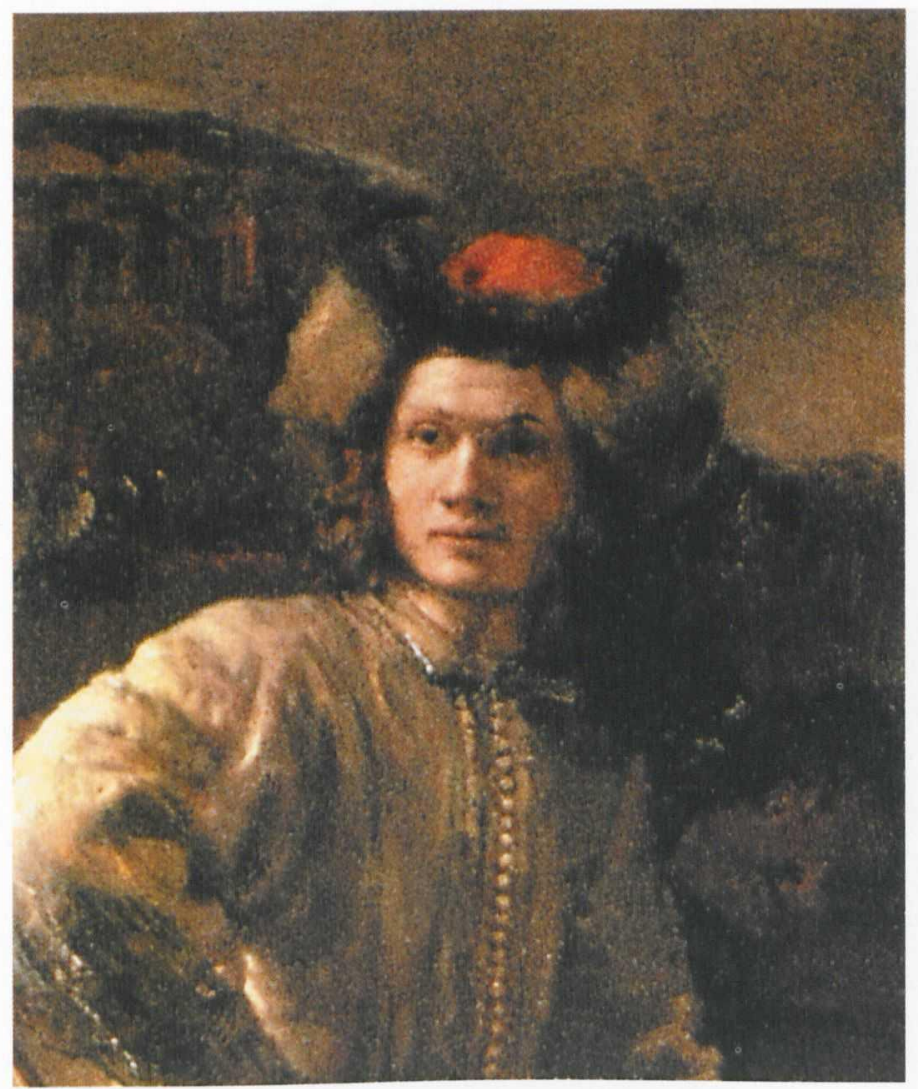

2) The head of Rembrandt's «Lisowczyk» (detail). Frick Collection, New York.

The first large monograph of the painting was published by the American Rembrandt scholar Julius S. Held in $1944^{7}$. $\mathrm{He}$ made the assumption that the picture was by Rembrandt and consequently made a penetrating analysis of all written sources that were available on the subject and drew iconographic analogies. He came to the conclusion that Rembrandt must have constructed the rider on the basis of some etchings, which were popular at that time, eg. by Stefano della Bella, and that he sketched the skeleton of a horse on display at the Dutch Anatomical Theatre. Held contested not only the supposition that the painting was a portrait but also the Polish character of the rider by putting the word "Polish" in quotationmarks. He stated that the youth's attire and arms were "Eastern" and that the costume could be Hungarian. The ideological meaning of the painting was most important for Held.
He perceived the rider as the Christian knight (Miles Christianus), fighting with the infidels. Undoubtedly, Held proved his great erudition, however, under the circumstances of war he had no access to the results of the latest research by Polish art scholars, particularly by the brilliant costume and arms historian, Bronisław Gembarzewski.

Held's hypothesis raised doubts in the circle of Western researchers of Rembrandt's oeuvre. In 1948 W. R. Valentiner came up with a suggestion that the rider was an imaginary portrait of a mythical Dutch national hero, Gysbrecht van Amstel, whose exciting adventures led him to Poland. To support his thesis Valentiner referred to Joast van den Vondel's play presenting Gysbrecht's history, which was popular in $1657 .^{8}$

In 1963 at the invitation of the American Association of Museums and at Professor S. Lorentz's request I made a trip to the United States. As I was engaged in research on the history of costume and arms, immediately after my arrival I turned my steps to the Frick Gallery in Manhattan. A close look the painting proved that it was a phenomenon of unusual stylistic homogeneity and objective genuineness in all elements of the attire, arms and armour. After my return to Poland I quickly did a study of the costume and weapons of the Lisowczyk in which I was able to prove convincingly, drawing a large number of comparisons, that the painting was a portrait and that Rembrandt could not paint it on the basis of second-hand models, for example della Bella's etchings, or dress the model in a costume compiled from his own collection of garments, as it is highly improbable that he could possess such a homogenous and unmistakably characteristic suit. In my opinion the rider's clothing is that of an officer of the Polish light cavalry, painted around the middle of the $17^{\text {th }} \mathrm{c}$., not different in style from the famous riders of the Lisowski corps who had ended their stormy career some twenty years earlier. My treatise was published in "Biuletyn Historii Sztuki" in $1964^{9}$. It drew the particular attention of Jan Białostocki whose interest substantially contributed to the publishing of the English version of my article in the Bulletin of the National Museum in Warsaw ${ }^{10}$. In this way it reached Rembrandt scholars abroad and provoked numerous repercussions in a series of polemics and speculative articles.

Mieczysław Paszkiewicz, who was in London at that time, in his review of the Polish text pointed out some evident mistakes occurring in it and proclaimed himself in favour of della Bella's influence on Rembrandt but, at the same time, he did not exclude the possibility that the artist could see Polish riders in the streets of Amsterdam ${ }^{11}$.

Held, who had been admired as the authority on the subject, was indignant at the attack and had his study of 1944 


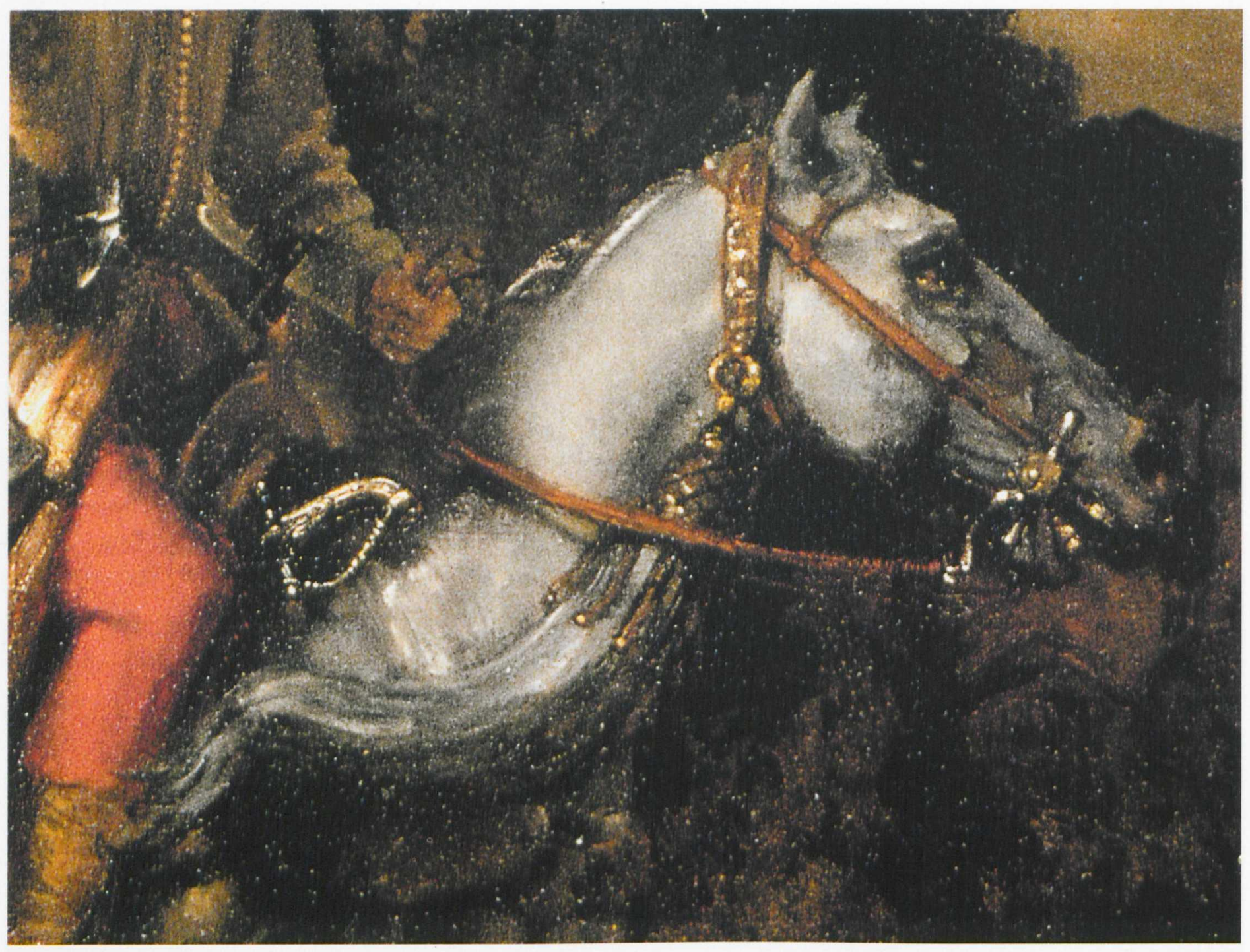

3) The horse of Rembrandt's «Lisowczyk» (detail). Frick Collection, New York.

republished in a collection of different works on Rembrandt in order to write in the annex that the Kraków treatise had a "local" character and that it could in no way change his conviction that the rider was an allegorical representation of the Christian knight $^{12}$.

In the same year 1969 Jan Białostocki came up with his own interpretation of the painting, perceiving in the youth the figure of Jonasz Szlichtyng, a Socinian Pole who stayed in Amsterdam in the middle of the $17^{\text {th }} \mathrm{C}$., a fighter for freedom and tolerance and author of "Eques Polonus". This very title was the strongest proof in the argumentation because it could be the source of Rembrandt's inspiration ${ }^{13}$.

Most of the authors of the subsequent studies of the question recognized without any doubts the "Polish character" of 


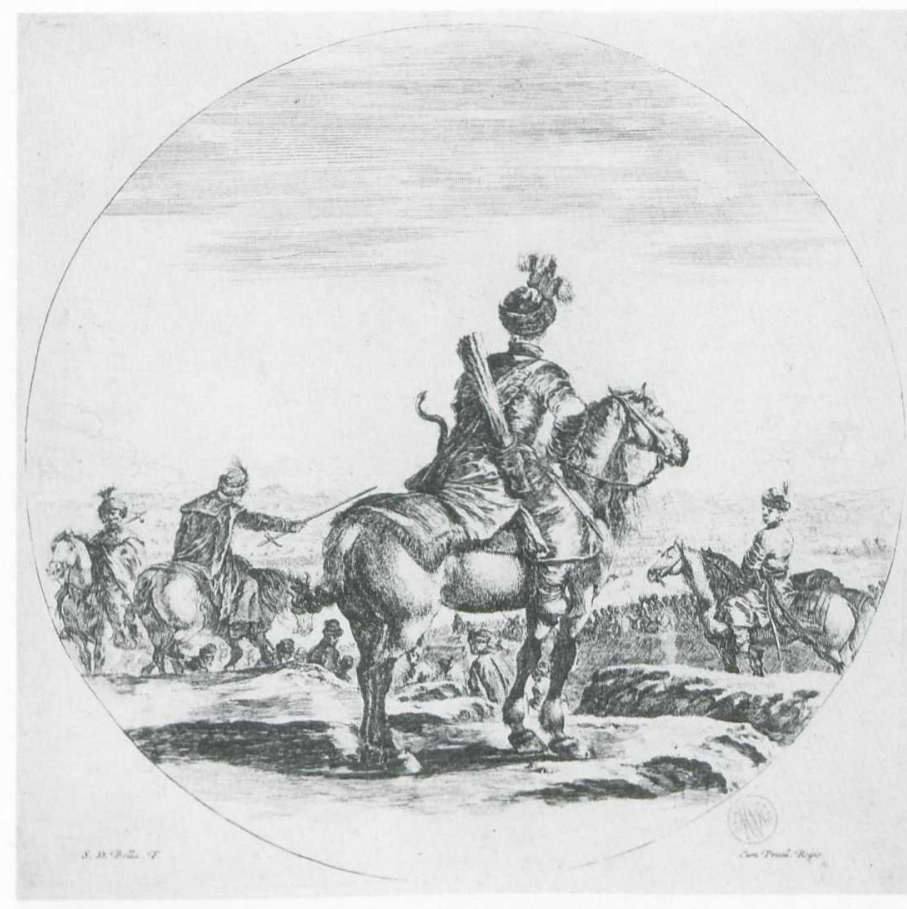

4) Stefano della Bella, «Polish Rider». National Museum, Cracow.

the rider. On the other hand, they concentrated on the identification of the figure and discussion on whether the painting was a portrait of a particular person or an imaginary, allegorical vision. In 1970 Colin Campbell published an article in which he suggested that the rider was the biblical Prodigal Son $^{14}$. A few years later he repeated his thesis in the German version of the same article ${ }^{15}$. The Bible served also other authors as a basis for their hypotheses in which they associated the rider with David or Absalom. Others looked for the source of their interpretations in the theatre, and thus, thanks to the rider's "Mongol" costume and under the influence of the contemporary drama about the ruler of Samarkand ${ }^{16}$, came to believe that the youth was Tamerlane in pursuit of Beyazit. Still another hero in those speculations was "Sigismund, Prince of Poland".

Another group of art scholars put forward their view that the painting was a portrait of a member of the Ogiński family. In their opinion the campfire that can be seen at the foot of the mountain in the background of the picture is a secret key to

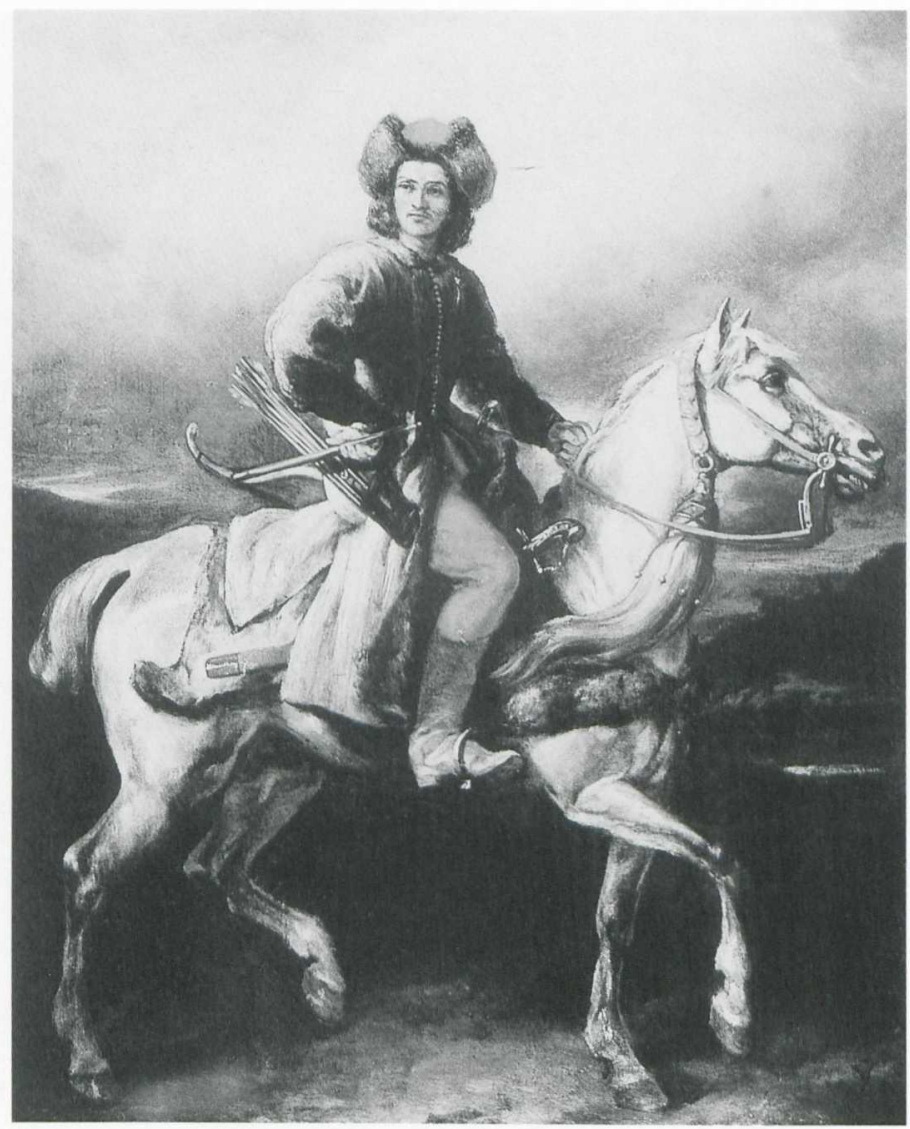

5) Juliusz Kossak «Lisowczyk» (after Rembrandt). National Museum, Warsaw.

the name. Marcjan Aleksander Ogiński (who died in 1690) or Szymon Karol Ogiński (who died in 1699) were most often named as sitters because they visited the Netherlands sometime in the middle of the $17^{\text {th }} \mathrm{c}$. and could meet Rembrandt. In 1974 an excellent article by Ben Broos was published in a magazine "Simiolus"17. Its author had no doubts that the rider was Polish. He believed that this was Szymon Karol Ogiński, who married a Dutch woman. On the other hand, Juliusz Chrościcki in his article "Rembrandt's Polish Rider. Allegory or Portrait?", published in the book commemorating Jan Bialostocki "Ars Auro Prior", summed up the polemics and recognized the youth as Marcjan Ogiński, a corporal in the Lithuanian army whose portrait was painted by Ferdynand Bol in the years 1650-54. In point of fact, the model has a phy- 


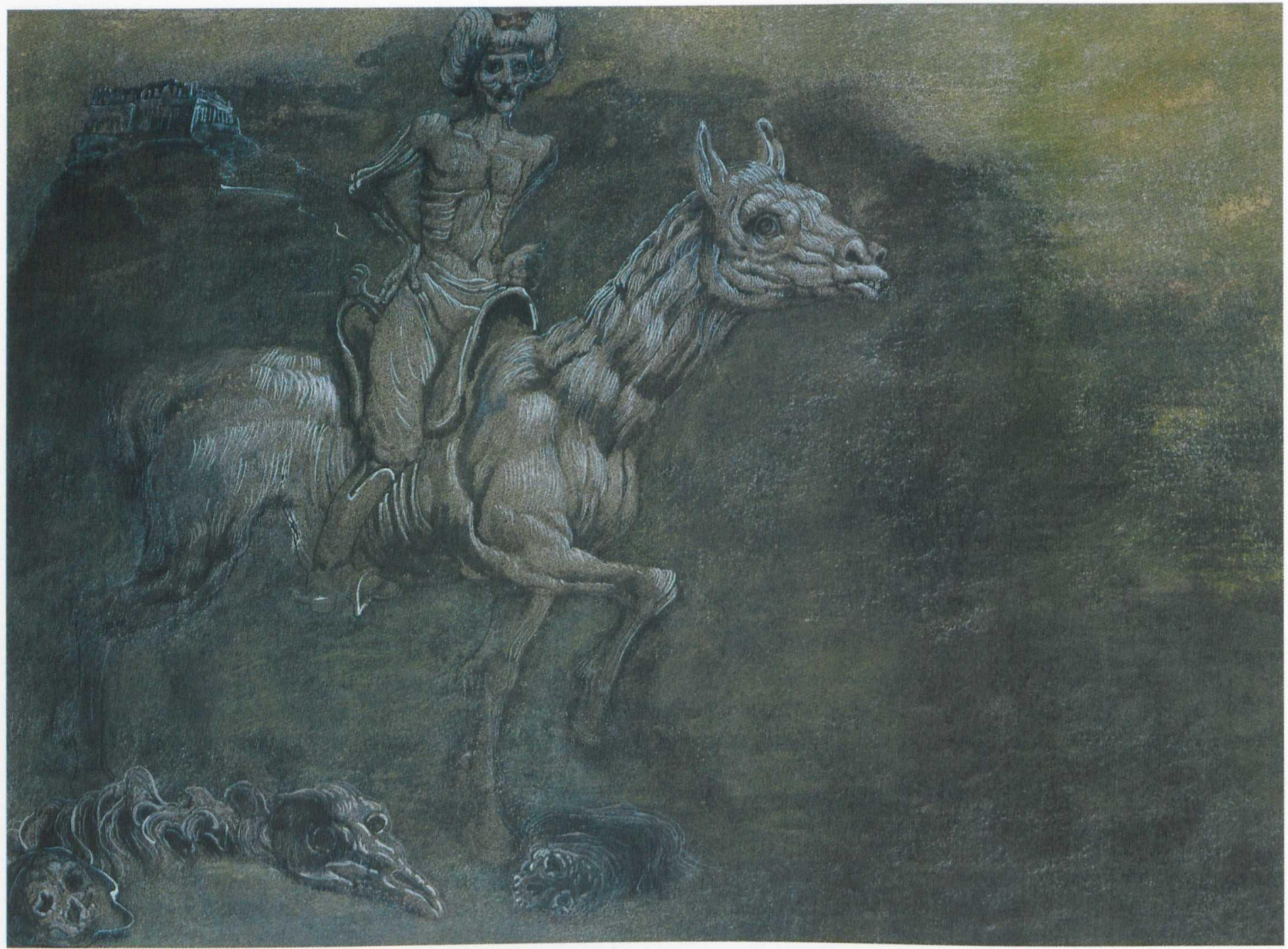

6) Jan Lebenstein «Lisowczyk» (after Rembrandt). Private collection.

siognomy similar to that of the Lisowczyk and wears the same kind of a cap ${ }^{18}$.

The critical moment in the history of the Lisowczyk came in 1984 when Josua Bruyn in a journal "Oud Holland" called in question Rembrandt's authorship of the painting and suggested that it could be attributed to the master's pupil, Willem Drost. Although this surprising opinion was expressed somewhat casually and lacked the support of complete argumenta- tion, as the whole article was a review of Werner Sumowski's work on Rembrandt's school, it still caused an uproar in the circle of art historians and museum curators due to Bruyn's authority and strong position in professional circles. ${ }^{19} \mathrm{He}$ was a member of the Rembrandt Research Project at the Rijksmuseum in Amsterdam, an informal committee founded by Dutch art scholars in 1968 to study paintings by Rembrandt. In the beginning the programme was carried out 
by six scholars with Bruyn as the chairman, i.e.: B. Haak (conservator and founding father), S. H. Levie, P. J. J. van Thiel, J. A. Emmens and J. G. van Gelder. After the death of the latter two, Ernest van de Wetering joined the team and soon became its leader. The reason for establishing the Project was an evident overabundance of works attributed to Rembrandt. The scholars decided to purge the artist's oeuvre basing on very precise stylistic, iconographic and technologic studies with the use of the most modern methods of investigation, including autoradiography, that is the analysis of the painter's character expressed by the brush strokes. The adopted rule was the direct examination by two members of the project of every painting irrespective of its place of display all over the world, basing mainly on Horst Gerson's catalogue of Rembrandt's works which comprises 420 masterpieces. The team assumed that their work would result in the rejection of 100-150 paintings. Obviously, the Project arouse keen interest among art historians and concern among museum curators who had Rembrandts in their galleries. It so happened that some private owners of paintings attributed to the master did not allow the RRP members into their homes. The Project intended to publish the corpus of Rembrandt paintings grouped according to three categories, i.e.: A - paintings recognized as authentic Rembrandts, B - disputable Rembrandts, C - rejected works. Up to 1990 the RRP team managed to examine the paintings dated before 1642 when The Night Watch was painted, so still before the date when the Lisowczyk was created. Three volumes of the "Corpus" were published in 1982, 1986 and 1989. The fourth volume, containing the opinion on the Lisowczyk was scheduled for the end of 1998.

Bruyn's shocking judgement was expressed before a general opinion was passed by other RRP members. Still their reservations as to whether the Lisowczyk was by Rembrandt despite its evident artistry and uniqueness had been known. Bruyn pointed out the soft outline of the rider's figure, which, in his opinion, was unlike Rembrandt, and indicated a female artistic temperament instead. Haak criticized disproportions in the figure of the rider and the strangeness of the horse, the nondescript background and the lack of the brush strokes typical of Rembrandt. De Wetering mentioned the "corporeality" and "stability" of human figures characteristic for Rembrandt but missing in the rider, who is too unsubstantial and vibrating in the unreal gleam, and the lack of close association between the background and the rider, which is indicative of a painter other than Rembrandt.

However, all those objections verged on subjectivism. Naming Drost the alleged author of the Lisowczyk was not convincing because the figures in his paintings, which were smooth and sloppy, had nothing in common with the Lisowczyk. Both the admirers and critics of the Lisowczyk have always displayed their deep appreciation for the painting and fascination with the enigmatic aura of the rider's chase after the desired object. The curators of the Frick Gallery faced the criticism calmly. Under no circumstances did they intend to change the painting's label or catalogue entries. Instead, they readily made the painting available for subsequent examinations, but carefully controlled whether its substance was left intact. It was a well-known fact that the painting had undergone conservation a few times before and that a strip of canvas $10 \mathrm{~cm}$ in width, showing the hooves, was attached to its lower rim and that some parts of the figure, including the cap, had also been retouched ${ }^{20}$.

The questions connected with the Lisowczyk were recently discussed by the American art critic and publicist Antony Bailey in his book "Responses to Rembrandt. Who painted the Polish Rider?" which was published in New York in 199321. Bailey's book is tremendously significant. The author not only presented honestly the complex of issues related to the painting but also indicated tactfully different defects in the work of the RRP team.

Bailey also published his interview with the senior Rembrandt scholar, J. S. Held, who started this great debate about the Polish Rider in 1944. Held criticized the RRP scholars, maliciously calling them "the Amsterdam mafia". $\mathrm{He}$ expressed his unceasing admiration for the Lisowczyk, whose reproduction he kept in his study. He agreed eventually that the rider's outfit was Polish and that this could be Marcjan Ogiński, although the representation was not a direct portrait of him. The removal of quotation marks from the term "Polish" afford us deep satisfaction ${ }^{22}$.

In April 1993 the members of the Rembrandt Research Project published an open letter in the "Burlington Magazine" in which they announced changes in their team. The following scholars ended their work for the Project: J. Bruyn, B. Haak, S. H. Levie and P. J. J. van Thiel. From then on further research aiming at the completion of the job of redefining Rembrandt's oeuvre and publication of the fourth and fifth volumes of the "Corpus" was to be accomplished by a small team under Ernst van de Wetering's leadership and in cooperation with specialists in different fields in order to ensure genuine results ${ }^{23}$

In February 1998 I received from de Wetering a text on the Lisowczyk, intended for publication in the fourth volume of the "Corpus," which was accompanied with a request to review it and, if necessary, correct the Polish terminology. The study is in all respects remarkable. It sums up our present knowledge of the Polish Rider and constitutes the basis for any future 
research. In the introductory part it mentions Bruyn's suggestion that the painting should be attributed to Drost and a detailed iconographic description. The painting was examined four times by the RRP members: by J. Bruyn and B. Haak in April 1969, then in December 1989, November 1994 and May 1996. E. van de Wetering participated in the three latter examinations ${ }^{24}$. The study contains a precise description of the canvas, its undercoat and paint layer, including the results of X-ray examination, and discusses the traces of the initial "R". It presents extensive commentaries concerning the interpretation of the painting by Jan Białostocki and Juliusz Chrościcki. My own opinion was quoted a number of times and the results of my studies on the rider's costume and arms approved. The links between Poland and the Netherlands in the $17^{\text {th }}$ c., which indicated the rider's "Polish character", were extensively discussed. An endavour was made to justify Bruyn's opinion, excluding his conception of attributing the painting to Drost. It was found out that beside the parts which were unquestionably painted by Rembrandt there are also parts denoting the hand of a different artist. One can conclude that the painting was started by Rembrandt in 1655 but left unfinished by the Master and that it bears the marks of later additions painted by someone else's hand ${ }^{25}$. The rider in the Polish costume and arms is a portrait of a real or imaginary Pole on a visit in Amsterdam in the middle of the $17^{\text {th }} \mathrm{c}$. The study ends with a presentation of an exceptional history of the painting which still continues to stir up strong emotions.
The paintings of great masters always enchant, fascinate, and intrigue, affecting, in particular, next artists, who, thanks to their innate talents, are able to notice those painterly nuances which can't be seen by dilettanti. Also the Lisowczyk has such enormous power of inspiration.

It is generally known that when the painting was to be taken from the gallery in Dzików to the New World, the Count Tarnowski ordered to make its exact replica. Unfortunately, it was burnt during the fire which broke out in the manor and we do not know to what extent it was a replica of the original. The Lisowczyk was copied many times but there also appeared its interpretations done by artists in the $19^{\text {th }} \mathrm{c}$. Juliusz Kossak, the most outstanding Polish painter of horses and historical scenes (along with Piotr Michałowski and Józef Brandt), was very interested in this painting. His Lisowczyk in the National Museum in Warsaw is very close to the original. The youth's attire and weapons testify to his Polish provenance. He is, however, deprived of that mysterious Rembrandtesque aura. The horse is a thoroughbred Arabian, since Kossak loved that breed.

Jan Lebenstein, the famous Polish painter and graphic artist, who died in June 1999, put a surprising interpretation on the Rembrandtesque work. His Lisowczyk is a horseman, the harbinger of death, which can be suggested by the skeleton protruding from earth's surface. Lebenstein contrasted the dramatic Romanticism of the twentieth century, the time of wars, upheavals and annihilation, with Kossak's sentimental nineteenth-century Romanticism. 
A version of this article was read at the National Museum in Warsaw in November 1998 during a ceremonial session of the Association of Art Historians held on the occasion of the $10^{\text {th }}$ anniversary of Prof. Jan Białostocki's death.

1 In the latest Polish literature there is a tendency, caused by American influence, to replace the title Lisowczyk with the Polish Rider. I am in favour of preserving the traditional title in our national literature.

2 A. Ciechanowiecki, "Notes on the Polish Rider", The Art Bulletin, 42, 1960, pp. 294-296.

3 Z. Żygulski, Jr., Muzea na świecie. Wstęp do muzealnictwa, Warszawa 1982, p. 66.

4 H. Wisner, Lisowczycy, Warszawa 1976, p. 128.

5 W. Bode, Studien zur Geschichte der holländischer Malerei, Berlin 1883, p. 499.

6 J. Bołoz-Antoniewicz, "Lisowczyk Rembrandta w posiadaniu hr. Tarnowskich w Dzikowie i jego wzór", Sprawozdanie Komisji Historii Sztuki AU, VIII, 1912, p. CCCLIX and J. Mycielski, "O Lisowczyku Rembrandta", ibidem, pp. CCCLXII-CCCLXIII.

7 J. S. Held, "Rembrandt's 'Polish Rider'", The Art Bulletin, 26, 1944, pp. 246-265.

8 W. R. Valentiner, "Rembrandt's Conception of Historical Portraiture", Art Quarterly, 11, 1948, pp. 116-135.

9 Z. Żygulski, Jr., "Lisowczyk Rembrandta. Studium ubioru i uzbrojenia”, Biuletyn Historii Sztuki, 1964, No 2, pp. 83-109.

10 Z. Żygulski, Jr., "Rembrandt's Lisowczyk. A Study of Costume and Weapons", Bulletin du Musée National de Varsovie, VI, 1965, Nos 2-3, pp.43-67.

${ }_{11}$ M. Paskiewicz, “'Jeździec polski’ Rembrandta”, Biuletyn Historii Sztuki, 1969, No 2, pp. 216-226 and Z. Żygulski, Jr., "Odpowiedź w kwestii Lisowczyka", ibid., pp. 227-228.

12 J. S. Held, Rembrandt's Aristotle and Other Studies, Princeton 1969, pp. 45-84.
13 J. Białostocki, "Rembrandt's 'Eques Polonus'”, Oud Holland, 84, 1969, pp. 163-176.

14 C. Campbell, "Rembrandt's Polish Rider and the Prodigal Son", Journal of the Warburg and Courtauld Institutes, 33, 1970, pp. 292-303.

15 O. von Simson and J. Kelch (editor), Neue Beiträge zur Rembrandt-Forschung, Berlin 1973, pp. 126-134.

16 J. Z. Kannegieter, "De Poolse Ruiter I-II", Kroniek van het Rembrandthuis, 24, No 4, 1970; L. S. Slatkes, Rembrandt and Persia, New York 1983; G. Schwartz, Rembrandt, His Life, His Paintings, New York 1985.

17 B. Broos, "Rembrandt's Portrait of a Pole and His Horse", Simiolus, 7, No 4, pp. 192-218.

18 J. Chrościcki, "Rembrandt's 'Polish Rider'. Allegory or Portrait?", in: Ars Auro Prior. Studia loanni Bialostocki Sexagenario Dedicata, Warszawa 1981, pp. 441-448.

19 W. Sumowski, Gemälde der Rembrandt-Schüler, vols. 1-5, Landau (Germany) 1983-1990 and J. Bruyn, "Review of Gemälde der Rembrandt-Schüler", Oud Holland, 98, 1984, pp. 146-162.

20 I made this observation in my article in 1964 and tried to reconstruct its original look, Z. Żygulski, Jr., "Lisowczyk Rembrandta...", op. cit., ill. 19.

21 I wish to express my gratitude to Ms Dorota Dec, Curator of the Gallery of Painting at the Czartoryski Museum in Kraków for bringing the book from New York.

22 A. Bailey, Responses to Rembrandt. Who painted the 'Polish Rider', New York 1993, pp. 94-96.

23 Ibid., pp. 115-116.

24 The fact that the examination was repeated four times proves the difficulty and significance of the problem.

25 E. van de Wetering repeated his opinion in his latest work: Rembrandt. The Painter at Work, Amsterdam 1998, pp. 207-210. 